\title{
Susceptibility of Echinochloa populations to cyhalofop-butyl in Southern region of Brazil and impact of the weed phenology on its efficacy of control
}

\author{
Augusto Kalsing ${ }^{*}$ Sérgio Mateus Tronquini ${ }^{1}$ Carlos Henrique Paim Mariot $^{1}$ Rogerio da Silva Rubin ${ }^{1}$ \\ Angela Da Cas Bundt ${ }^{1}$ Dauri Aparecido Fadin ${ }^{1}$ Luiz Henrique Marques ${ }^{1}$
}

\footnotetext{
${ }^{1}$ Crop Protection Research and Development, Dow Agrosciences Industrial Ltda, 14.171, São Paulo, SP, Brasil. E-mail: Akalsing@dow.com.br. ${ }^{*}$ Corresponding author.
}

\begin{abstract}
Cyhalofop-butyl stands out among the herbicides in the control of imidazolinone-resistant Echinochloa species; but, rice farmers are not always satisfied with the control achieved with this herbicide. The objectives were to evaluate in regional scale the susceptibility of Echinochloa populations to cyhalofop-butyl, and quantify the effect of the weed phenology on its efficacy of control. For this, three trials were carried out under greenhouse conditions with a fully random design, using Echinochloa populations collected in rice fields in the southern region of Brazil. In two trials, the susceptibility level of 156 (2012/13 growth season) and 103 (2013/14 growth season) populations were evaluated with

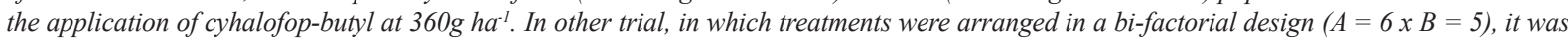
evaluated six cyhalofop-butyl rates and five phenological stages of $\boldsymbol{E}$. crus-galli populations. Echinochloa populations had showed differential susceptibility to cyhalofop-butyl, especially in the 2013/14 growth season, where 20 out of the 103 populations had control lower than $90 \%$. The efficacy of this herbicide was inversely proportional to the phenological stage, and the application timing delay contributed directly to the decrease of susceptibility to the herbicide. Cyhalofop-butyl is an effective alternative to control imidazolinone-resistant Echinochloa populations, as long as the application timing occurs in the early phenological stages (2 to 4 leaves).

Key words: barnyardgrass, development stage, imidazolinones, Echinochloa crus-galli, Echinochloa colona.
\end{abstract}

Suscetibilidade de populações de Echinochloa a cyhalofop-butyl na região Sul do Brasil e impacto da fenologia da infestante sobre a eficácia do seu controle

RESUMO: Cyhalofop-butyl destaca-se dentre os herbicidas usados no manejo de populações de capim-arroz resistente às imidazolinonas, mas nem sempre o orizicultor fica satisfeito com o resultado obtido com este herbicida. Objetivou-se avaliar a suscetibilidade de populações de capim-arroz (Echinochloa spp.) ao cyhalofop-butyl e, quantificar o efeito da fenologia da infestante sobre a eficácia do seu controle. Para isto, três experimentos foram realizados em casa de vegetação com delineamento inteiramente casualizado, utilizando-se populações de capim-arroz coletadas na região Sul do Brasil. Em dois experimentos, a suscetibilidade de 156 (safra 2012/13) e 103 (safra 2013/14) populações foram avaliadas frente à aplicação do herbicida cyhalofop-butyl na dose de $360 \mathrm{~g} \mathrm{ha} \mathrm{a}^{-1}$. Em outro experimento, em que se arranjaram os tratamentos em esquema bi-fatorial, foram avaliados seis doses do herbicida e cinco estádios fenológicos de populações de $\boldsymbol{E}$. crus-galli. Foi verificada variação na resposta das populações de capim-arroz ao cyhalofop-butyl, em especial na safra 2013/14, em que 20, das 103 populações testadas, tiveram controle menor que $90 \%$. A eficácia do controle foi inversamente proporcional ao estádio fenológico e, o atraso no controle da infestante contribui diretamente para a diminuição da sua suscetibilidade ao herbicida. Cyhalofop-butyl é uma alternativa eficaz para controlar capim-arroz resistente às imidazolinonas, desde que a aplicação ocorra nos estádios iniciais de desenvolvimento (2 a 4 folhas).

Palavras-chave: capim-arroz, estádio de desenvolvimento, imidazolinonas, Echinochloa crus-galli, Echinochloa colona.

\section{INTRODUCTION}

Species from the Echinochloa genus are frequently distributed over flooded rice fields in Brazil and worldwide, and historically includes a number of the most important weeds of this crop. In general, species from this genus have plants with intermediate characteristics and great morphological variability, and their field identification is very hard (DALAMAS et al., 2008). Therefore, in many situations, populations of the species Echinochloa crus-galli, E. crus-pavonis and E. colona, among others, are identified as Echinochloa complex (BORTOLY et al., 2015). These species present 
high adaptability level for interspecies competition, causing severe damages and yield losses even to lowly infested flooded rice fields (PANOZZO et al., 2014). Just one Echinochloa plant per $\mathrm{m}^{-2}$ caused enough negative interference to decrease the grain yield of flooded rice fields in Brazil ranging from 4 to 30\% (GALON et al., 2007).

Echinochloa species have herbicide resistant biotypes that were reported in various regions on Brazil and the world, and they are among the ten weed species with most number of resistance cases. In fact, the Echinochloa complex includes six species that are resistant to nine different herbicide action mechanisms, including various cases of multiple resistance to herbicides (HEAP, 2016). Over the last decade, in the southern region of Brazil, the constant use of imidazolinones on Clearfield $^{\circledR}$ rice has selected innumerous biotypes resistant to herbicides of this chemical group. This added up to the resistance of biotypes from the same species to the auxin-mimic quinclorac, with cases of multiple resistance as well, limiting the farmers' options for herbicides on controlling Echinochloa species on this region (ANDRES et al., 2007; MATZENBACHER et al., 2013).

Cyhalofop-butyl, 2-[4-(4-cyano-2fluorophenoxy) phenoxy] propionate, butyl ester is a systemic herbicide that controls annual and perennial grasses, and that has been used in agriculture for over two decades. As all the other aryloxyphenoxypropionate acids, it works by inhibiting the Acetyl Coenzyme A Carboxylase enzyme, which catalyzes the first synthesis route of oily acids (DÉLYE et al., 2003). It has physicalchemical characteristics that result into high selectivity over rice, due to low esterification and high metabolization of its molecules (RUIZSANTAELLA et al., 2006a). Conversely, it is very active on other grasses, such as the ones from the Echinochloa complex, giving high effectiveness to rates starting from $200 \mathrm{~g} \mathrm{ha}^{-1}$ (KIM et al., 2005). For these reasons, cyhalofop-butyl is one of the most widely used herbicides with this action mechanism for the control of grasses complex in flooded rice as well upland rice fields.

The use of alternative herbicides or their association with imidazolinones on the imidazolinone-resistant Echinochloa management has been a common practice in the Southern region of Brazil. Among the available herbicide options for this situation, cyhalofop-butyl stands out, since its action mechanism is different from imidazolinones (MATZENBACHER et al., 2015). However, in some cases, rice farmers are not satisfied with cyhalofopbutyl results, mainly when Echinochloa plants emerge at different times and are in variable growth stages at the application. In addition, cyhalofopbutyl is commonly utilized to rescue the control of imidazolinone-resistant Echinochloa which are in more advanced phenological stages of the plants, such as full tillering. This study was developed to evaluate the following two hypothesis: (i) populations of Echinochloa species has differential susceptibility to cyhalofop-butyl; (ii) the efficacy of control of this herbicide depends on the phenological stage of Echinochloa plants.

The objective was to evaluate the susceptibility of imidazolinone-resistant Echinochloa populations to cyhalofop-butyl, and quantify the effect of phenology stage of these weeds over the efficacy of control of cyhalofop-butyl.

\section{MATERIALS AND METHODS}

\section{Vegetal material \\ Three trials were performed in a} controlled environment greenhouse at the Experimental Station of Dow AgroSciences Ind. Ltda., in Mogi Mirim/SP, Brazil, on the 2012/13 and 2013/14 growth season. The plant material studied comes from seeds samples of Echinochloa crusgalli, E. crus-pavonis and E. colona collected in flooded rice fields in Rio Grande do Sul and Santa Catarina states, which are located in the geographic area between the geographic coordinates of latitude $26^{\circ} 27^{\prime} 00^{\prime \prime} \mathrm{S}$ to $33^{\circ} 31^{\prime} 08^{\prime}$ 'S and longitude $48^{\circ} 50$ ' $39^{\prime \prime} \mathrm{W}$ to $57^{\circ} 05^{\prime} 18^{\prime \prime} \mathrm{W}$. Fields were chosen based on the history usage of Clearfield ${ }^{\circledR}$ rice varieties, as well as imidazolinones herbicides, and ripe seeds were always collected in bulk from at least 25 plants. Plants were established using the method described by MATZENBACHER et al. (2013), and have grown over air temperature of $28 \pm 2^{\circ} \mathrm{C}$ and photoperiod of 12 hours (light/dark).

\section{Susceptibility of the populations to cyhalofop-butyl}

Two trials were designed as a fully random design using three or four repetitions whose one trial had 156 populations and other trial had 103 populations, respectively, on the 2012/13 and 2013/14 growth seasons. The treatment was cyhalofop-butyl at $360 \mathrm{~g} \mathrm{ha}^{-1}\left(\right.$ Clincher $^{\circledR}, 180 \mathrm{~g} \mathrm{~L}^{-1}$, EC, Dow AgroSciences) with the addition of mineral oil at $2 \%$ v. v. ${ }^{-1}$ (Joint $^{\circledR}$ Oil, $761 \mathrm{~g} \mathrm{~L}^{-1}, \mathrm{EC}$, Dow AgroSciences). This rate corresponds to $133 \%$ of the maximum rate recommended for Echinochloa 
control and was used for a better comparison of the susceptibility among the different populations. Each treatment repetition was composed by a $5 \mathrm{~L}$ plastic pot containing 25 Echinochloa plants, and herbicide application were always performed when plants reached 2 expanded leaves. The application was performed with a $\mathrm{CO}_{2}$ portable spray, equipped with XR Teejet 110.015 nozzles, and spray pressure of 40psi, reaching a spray solution volume equivalent to $100 \mathrm{~L} \mathrm{ha}^{-1}$.

\section{Phenology effect on cyhalofop-butyl effectiveness}

One trial was designed as a fully random design with bi-factor arrangement design $(A=6 x$ $\mathrm{B}=5$ ) and four repetitions; each repetition consisted of a 5L plastic pot containing five Echinochloa plants. For this trial, the vegetal material consisted of five barnyardgrass (E. crus-galli) populations of the 2012/13 growth season from several rice regions across Rio Grande do Sul State. The A factor consisted of six rates of cyhalofop-butyl, as following: $0,45,90,180,360$ and $720 \mathrm{~g} \mathrm{ha}^{-1}$ with the addition mineral oil at $2 \% \mathrm{v} . \mathrm{v}^{-1}$, as described in the previous section. The $\mathrm{B}$ factor consisted of five phenological stages, as following (BBCH scale): 2 leaves (12), 4 leaves (14), 2 tillers (22), 4 tillers (24) and full flowering (55) (HESS et al., 1997). The stages were defined when $50 \%+1$ of the plants reached the determined characteristic. Herbicide treatments applications were always performed as described in the previous section.

\section{Evaluations and statistic analysis}

The efficacy of control of Echinochloa populations was always evaluated 30 days after herbicide treatment application (DAT), using conventional scale of visual control, with values from 0 to $100 \%$. In the susceptibility trials, histograms of efficacy of control ranges were created to classify the Echinochloa populations according to their susceptibility to cyhalofopbutyl. In the phenology effect trial, the data was submitted to analysis of variance by $\mathrm{F}$ test $(\mathrm{P} \leq 0.05)$ and, subsequently, to non-linear regression analysis by three parameters logistic model. With the obtained functions, it was used the inverse equation principle to estimate $\mathrm{GR}_{50}$, that is, the herbicide rate that gives $50 \%$ of efficacy of control over Echinochloa plants. Finally, $\mathrm{GR}_{50}$ values of the populations were adjusted to the second order polynomial model, to estimate the relation between phenological stage and the response to cyhalofopbutyl herbicide.

\section{RESULTS}

Susceptibility of the populations to cyhalofop-butyl

The Echinochloa populations were satisfactorily controlled by cyhalofop-butyl in most situations ( $>80 \%$ control); but, they showed differential susceptibility to the treatment in both growth seasons (Figure 1). During the 2012/13 growth season, $360 \mathrm{~g} \mathrm{ha}^{-1}$ of cyhalofop-butyl presented high control over the 156 evaluated populations; in all situations, the minimum efficacy of control was $91 \%$. During the 2013/14 growth season, there has been higher variability in the response of populations to the same treatment, since 20 out of 103 populations presented lower than $90 \%$ response. Moreover, 3 out of 103 populations were not controlled in a satisfactory way ( $<80 \%$ control) and would possibly survive in a situation of flooded rice commercial field. This results pointed out the existence of some Echinochloa populations less sensitive to cyhalofopbutyl and not properly controlled, even with the use of higher rates than the maximum label one.

\section{Phenology effect on cyhalofop-butyl effectiveness} Efficacy of control varied based on the significant interaction between rate and phenological stage; this allowed the interaction decomposition with dose-response curves for each phenological stage. On table 1, the parameters of the logistic model equation for the five barnyardgrass are shown, in five phenological plant stages, obtaining high adjustment to the non-linear logistic model. It is possible to verify a clear decrease in the efficacy of control based on the progress of the barnyardgrass development, especially once the plants started the tillering growth stages. For example, when the plants were in the initial phenological stages ( 2 to 4 leaves), an effective control was obtained in most cases, using the label rates (from 180 to $315 \mathrm{~g} \mathrm{ha}^{-1}$ ); however, when the plants were in advanced phenological stages such as 2 to 4 tillers, barnyardgrass was only effectively controlled with the application of twice the rate on the label.

As plants developed, there was a decrease in control levels, since the obtained value for $\mathrm{GR}_{50}$ was proportional to the phenological weed stage, on the average of the five barnyardgrass populations (Figure 2). Actually, barnyardgrass was very sensitive when treated during the 2 and 4 leaf stages, since the average $\mathrm{GR}_{50}$ was obtained with lower than $100 \mathrm{~g}$ $\mathrm{ha}^{-1}$ cyhalofop-butyl rates. Conversely, in control situations during the most advanced phenological stages, the magnitude of $\mathrm{GR}_{50}$ grew exponentially, 


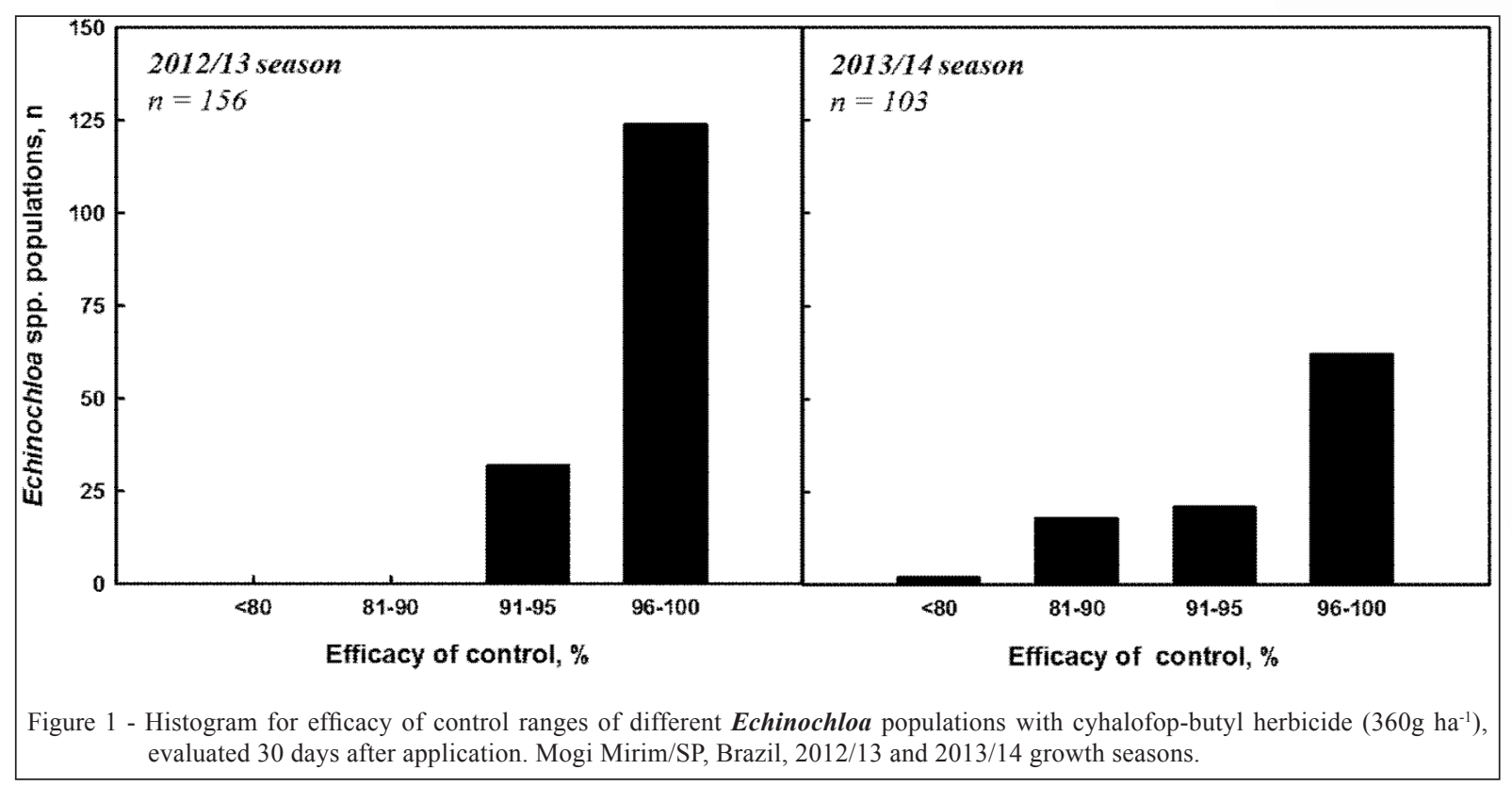

exceeding the herbicide rate of $400 \mathrm{~g} \mathrm{ha}^{-1}$ of cyhalofop-butyl. In fact, it was observed that the progress in each unit of the $\mathrm{BBCH}$ scale requires an increase of $3.3 \mathrm{~g} \mathrm{ha}^{-1}$ of cyhalofop-butyl herbicide, in order to obtain efficacy of control of $50 \%$. However, with barnyardgrass plants in advanced stages, as example full flowering, the increase in the rate only compensated for the decrease of weed control and not provided satisfactory control.

\section{DISCUSSION}

The Echinochloa complex increased its importance in rice farming during the last decade in Brazil and worldwide, due to the appearance of herbicide resistant biotypes in six species of this genus (HEAP, 2016). In Brazil, imidazolinones and/ or quinclorac resistant Echinochloa populations are widespread over flooded rice fields in the southern region of the country (MATZENBACHER et al., 2015). This problem requires a changing attitude from rice farmers and technicians, not only on alternative herbicide usage, but also on attention towards good practices for the use of these products. Thus, for the cyhalofop-butyl herbicide, this study addresses two topics that have great relevance for its efficacy of control over imidazolinone-resistant Echinochloa populations: (i) there is differential susceptibility among populations to cyhalofop-butyl herbicide (Figure 1); (ii) the performance of this herbicide depends on the phenological stage of the plants (Figure 2; Table 1).

In other studies with Echinochloa species, differential susceptibility to cyhalofopbutyl applied from 150 to $300 \mathrm{~g} \mathrm{ha}^{-1}$ rates occurred as well (VIDOTTO et al., 2007; DALAMAS et al., 2008). In these cases, higher sensibility was noticed in the $\boldsymbol{E}$. crus-galli species compared to $\boldsymbol{E}$. erecta, E. phyllopogon and $\boldsymbol{E}$. oryzoides, even though variations took place within each species. In the present research, the identification of species was not performed in susceptibility trials, since its objective was only to widely evaluate the response of populations in regional scale. In the phenology trial, the five populations evaluated were from the specie $\boldsymbol{E}$. crus-galli and differences were observed among them in the response to increased herbicide rates (Table 1). This may be related to populations' adaptations in metabolizing cyhalofop-butyl at higher level and/or speed velocity (RUIZ-SANTAELLA et al., 2006b; MATZENBACHER et al., 2015).

The effect of plant stage over herbicide control is widely known and has been shown in literature for Echinochloa species; it has been demonstrated for various herbicides (PINTO et al., 2008; PANOZZO et al., 2014). However, the present study is innovating in quantifying this effect 
Table 1 - Logistic type regression equations used to quantify the effect of the weed phenological stage and of cyhalofop-butyl rates over efficacy of control of barnyardgrass (E. crus-galli) populations, being evaluated 30 days after application. Mogi Mirim/SP, Brazil, 2012/13 growth season.

\begin{tabular}{|c|c|c|c|c|c|c|}
\hline \multirow{2}{*}{ Population } & \multirow{2}{*}{ Stage $(\mathrm{BBCH})$} & \multicolumn{3}{|c|}{ 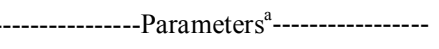 } & \multirow{2}{*}{$\mathrm{R}^{2 \mathrm{c}}$} & \multirow{2}{*}{$F^{d}$} \\
\hline & & $a$ & $b$ & $c^{b}$ & & \\
\hline 48URUG & 2 leaves (BBCH 12) & 99.6 & 3.0 & 34.4 & 0.99 & $4,646.4^{*}$ \\
\hline 69STMA & 2 leaves $(\mathrm{BBCH} 12)$ & 99.8 & 3.4 & 36.0 & 0.99 & $676.2^{*}$ \\
\hline 75SGAB & 2 leaves $(\mathrm{BBCH} 12)$ & 98.8 & 3.5 & 34.5 & 0.99 & $5,346.7^{*}$ \\
\hline 108ARGR & 2 leaves (BBCH 12) & 96.9 & 2.4 & 30.7 & 0.99 & $1,160.7^{*}$ \\
\hline 136PALM & 2 leaves $(\mathrm{BBCH} 12)$ & 98.2 & 2.4 & 32.4 & 0.99 & $1,232.3^{*}$ \\
\hline 48URUG & 4 leaves $(\mathrm{BBCH} 14)$ & 96.1 & 19.8 & 62.0 & 0.98 & $476.8^{*}$ \\
\hline 69STMA & 4 leaves $(\mathrm{BBCH} 14)$ & 96.4 & 24.1 & 65.6 & 0.98 & $473.4^{*}$ \\
\hline 75SGAB & 4 leaves (BBCH 14) & 93.9 & 12.4 & 76.7 & 0.98 & $298.1^{*}$ \\
\hline 108ARGR & 4 leaves $(\mathrm{BBCH} 14)$ & 100.2 & 59.0 & 127.3 & 0.97 & $291.0^{*}$ \\
\hline 136PALM & 4 leaves (BBCH 14) & 91.5 & 61.4 & 115.3 & 0.95 & $134.9^{*}$ \\
\hline 48URUG & 2 tillers (BBCH 22) & 92.9 & 34.1 & 100.3 & 0.99 & $639.0^{*}$ \\
\hline 69STMA & 2 tillers (BBCH 22) & 99.4 & 40.4 & 110.6 & 0.99 & $888.4^{*}$ \\
\hline 75SGAB & 2 tillers (BBCH 22) & 92.7 & 58.2 & 190.3 & 0.98 & $350.6^{*}$ \\
\hline 108ARGR & 2 tillers (BBCH 22) & 81.4 & 54.7 & 119.7 & 0.94 & $53.7^{*}$ \\
\hline 136PALM & 2 tillers (BBCH 22) & 93.1 & 109.5 & 245.9 & 0.94 & $118.9^{*}$ \\
\hline 48URUG & 4 tillers (BBCH 24) & 93.0 & 19.4 & 52.8 & 0.98 & $416.7^{*}$ \\
\hline 69STMA & 4 tillers (BBCH 24) & 88.6 & 29.5 & 58.9 & 0.92 & $88.5^{*}$ \\
\hline 75SGAB & 4 tillers (BBCH 24) & 82.8 & 12.5 & 36.6 & 0.91 & $77.9^{*}$ \\
\hline 108ARGR & 4 tillers (BBCH 24) & 89.5 & 85.3 & 153.5 & 0.94 & $120.4^{*}$ \\
\hline 136PALM & 4 tillers (BBCH 24) & 90.5 & 87.1 & 143.2 & 0.93 & $101.5^{*}$ \\
\hline 48URUG & Flowering (BBCH 55) & 69.9 & 53.9 & 138.0 & 0.93 & $98.8^{*}$ \\
\hline 69STMA & Flowering (BBCH 55) & 88.5 & 134.7 & 304.5 & 0.97 & $234.6^{*}$ \\
\hline 75SGAB & Flowering (BBCH 55) & 53.9 & 39.1 & 82.4 & 0.94 & $118.5^{*}$ \\
\hline 108ARGR & Flowering (BBCH 55) & 30.7 & 158.6 & 346.0 & 0.89 & $61.0^{*}$ \\
\hline 136PALM & Flowering (BBCH 55) & 32.2 & 95.4 & 197.1 & 0.88 & $55.9^{*}$ \\
\hline
\end{tabular}

${ }^{\mathrm{a}}$ Logistic type equation $\left[\mathrm{y}=\mathrm{a} /\left(1+\left((\mathrm{x} / \mathrm{c})^{\mathrm{b}}\right)\right)\right]$, where $a, b$ and $c$ are the parameters and $x$ and $y$ are the variables. ${ }^{\mathrm{b}}$ Parameter that indicates the cyhalofop-buty rate $\left(\mathrm{g} \mathrm{ha}^{-1}\right)$ that gives $50 \%$ of reduction of the parameter $a$ of the equation. ${ }^{\mathrm{c}}$ Determination coefficient value of the equation. ${ }^{\mathrm{d}} \mathrm{F}$ value significant at $1 \%$ of probability of experimental error.

for cyhalofop-butyl and in demonstrating that it may be even higher in cases of populations that are less sensitive to it. Thus, when the presence of imidazolinone-resistant Echinochloa populations is suspected, rice farmers must proceed with the application of cyhalofop-butyl as soon as possible. These pieces of information have great practical applicability, especially for the timing of control, justifying its implementation at early development stages of Echinochloa and, consequently, giving the chance to reduce cyhalofop-butyl rates, its application cost and its selection pressure over other weed species that can infest flooded rice as well as upland rice fields.

\section{CONCLUSION}

Imidazolinone-resistant Echinochloa populations shown differential susceptibility to cyhalofop-butyl herbicide, with cases in which they survived the exposure to the maximum rate on the herbicide label. The efficacy of this herbicide was inversely proportional to the phenological stage, and the application timing delay contributes directly to the decrease of susceptibility to the herbicide. Cyhalofop-butyl is an effective alternative to control imidazolinone-resistant Echinochloa populations, as long as the application timing occurs in the early phenological stages ( 2 to 4 leaves). 


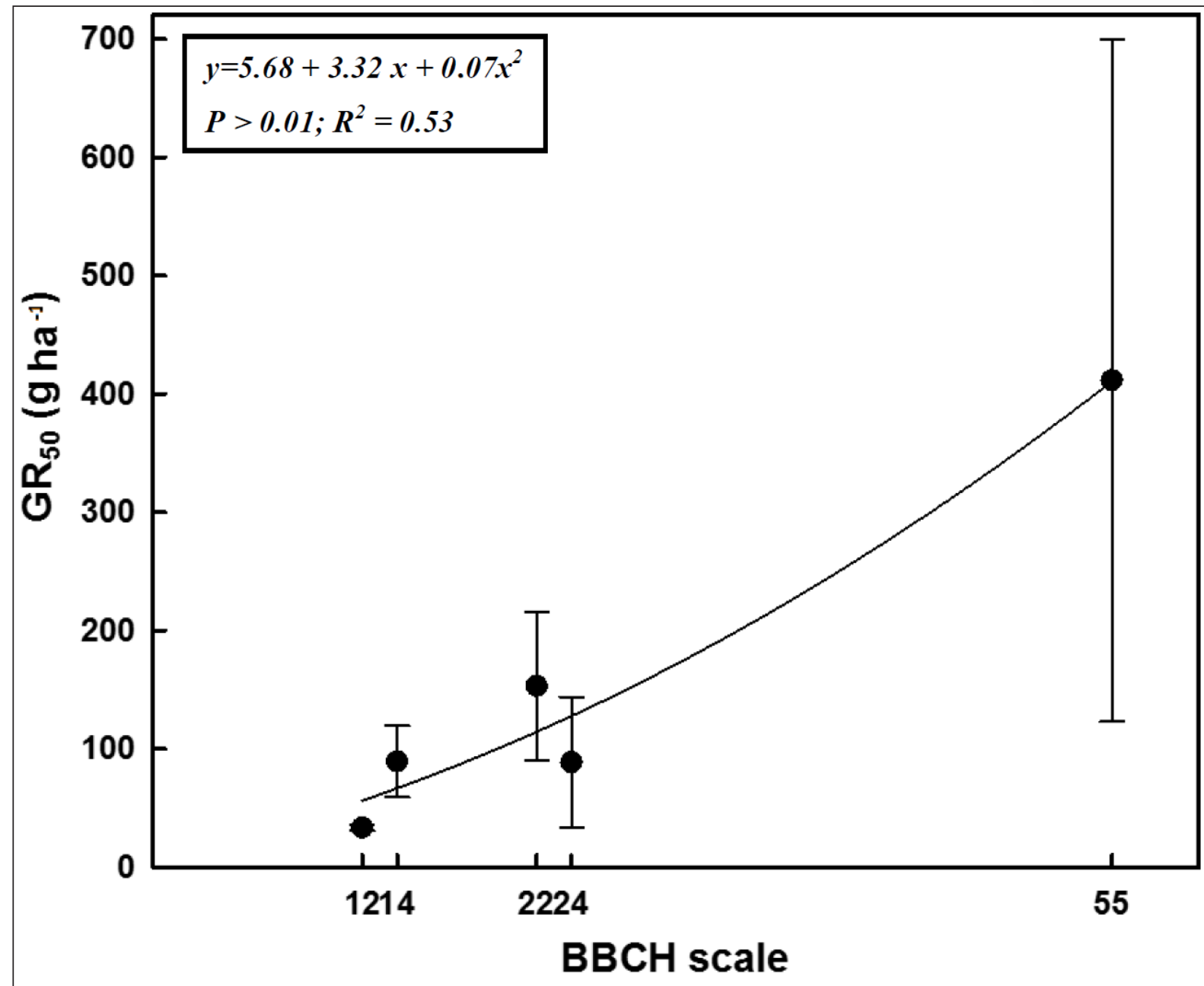

Figure 2 - Necessary cyhalofop-butyl rate for $50 \%$ efficacy of control $\left(\mathrm{GR}_{50}\right)$ on barnyardgrass (E. crus-galli) populations, adjusted to the phenological stages ${ }^{a}$ of plants, evaluated 30 days after the application. Mogi Mirim/SP, Brazil, 2012/13 growth season. ${ }^{\text {aSecond }}$ order polynomial equation $\left(\mathrm{y}=\mathrm{a}+\mathrm{bx}+\mathrm{cx}^{2}\right)$, where $a, b$ and $c$ are the parameters and $x$ and $y$ are the variables. ${ }^{\mathrm{b} B C H} 12(2$ leaves), BBCH 14 (4 leaves), BBCH 22 (2 tillers), BBCH 24 (4 tillers) and BBCH 55 (full flowering).

\section{ACKNOWLEDGEMENTS}

The authors thank the Sales Technical Representatives and the Distributors at Dow Agrosciences Industrial Ltda. for collecting and sending vegetal material in flooded rice fields during two growth seasons.

\section{REFERENCES}

ANDRES, A. et al. Detection of Echinochloa sp resistance to quinclorac in rice fields in Southern Brazil. Planta Daninha, v.25, p.221-226, 2007. Available from: $<$ http://www.scielo.br/scielo.php?script=sci_arttext\&pid $=$ S0100-83582007000100025 $>$. Accessed: Jun. 01, 2016. doi: 10.1590/S0100-83582007000100025.

BORTOLY, E.D. et al. Identificação de espécies do gênero Echinochloa através de descritores morfológicos e moleculares.
In: CONGRESSO BRASILEIRO DE ARROZ IRRIGADO, 9., 2015, Pelotas, RS. Anais... Pelotas: Empresa Brasileira de Pesquisa Agropecuária, 2015. p.856-859. Available from: <http:// www.cbai2015.com.br/docs/trab-2-1152-327-1507092118.pdf 7000100025>. Accessed: Jun. 01, 2016.

DALAMAS, C. A. et al. Morphological and physiological variation among species of the genus Echinochloa in northern Greece. Weed Science, v.56, p.416-423, 2008. Available from: <http:// www.bioone.org/doi/full/10.1614/WS-07-168.1>. Accessed: Jun. 01, 2016. doi: 10.1614/WS-07-168.1.

DÉLYE, C. et al. An isoleucine residue within the carboxylTransferase domain of multidomain acetyl-coenzyme A carboxylase is a major determinant of sensitivity to aryloxyphenoxypropionate but not to cyclohexanedione inhibitors. Plant Physiology, v.132, p.1716-1723, 2003. Available from: <http://www.plantphysiol.org/ content/132/3/1716.short>. Accessed: Jun. 01, 2016. doi: 10.1104/ pp.103.021139. 
GALON, L. et al. Estimation of grain yield loss in rice (Oryza sativa) cultivars due to interference by barnyardgrass (Echinochloa spp.). Planta Daninha, v.25, p.221-226, 2007. Available from: $<$ http://www.scielo.br/scielo.php?script=sci arttext\&pid= S010083582007000400006>. Accessed: Jun. 01, 2016. doi: 10.1590/ S0100-83582007000400006.

HEAP, I. The international survey of herbicide resistant weeds. Available from: <http://www.weedscience.com>. Accessed: Jun. 01, 2016.

HESS, M. et al. Use of the extended BBCH scale - general for the descriptions of the growth stages of mono- and dicotyledonous weed species. Weed Research, v.37, p.433-441, 1997. Available from: $<$ http://onlinelibrary.wiley.com/doi/10.1046/j.1365-3180.1997. d01-70.x/full>. Accessed: Jun. 01, 2016. doi: 10.1046/j.13653180.1997.d01-70.x.

KIM, J.S. et al. Physiological basis of differential phytotoxic activity between fenoxaprop-P-ethyl and cyhalofop-butyl-treated barnyardgrass. Weed Biology Managment, v.5, p.539-545, 2005. Available from: <http://onlinelibrary.wiley.com/doi/10.1111/ j.14456664.2005.00158.x/ abstract>. Accessed: Jun. 01, 2016. doi: 10.1111/j.1445-6664.2005.00158.x.

MATZENBACHER, F. O. et al. Distribution and analysis of the mechanisms of resistance of barnyardgrass (Echinochloa crusgalli) to imidazolinone and quinclorac herbicides. Journal of Agricultural Science, v.153, p.1-15, 2015. Available from: $<$ http://journals.cambridge.org/action/displayAbstract?fromPage $=$ online\&aid $=9834660>$. Accessed: Jun. 01, 2016. doi: 10.1017/ S0021859614000768.

MATZENBACHER, F.O. et al. Rapid diagnosis of resistance to imidazolinone herbicides in barnyardgrass (Echinochloa crus-galli) and control of resistant biotypes with alternative herbicides. Planta Daninha, v.31, p.645-656, 2013. Available from: $\quad<$ http://www.scielo.br/scielo.php?script=sci_arttext\&pid $=\mathrm{S} 0100-83582013000300016>$. Accessed: Jun. 01, 2016. doi: $10.1590 / \mathrm{S} 0100-83582013000300016$.

PANOZZO, L. E. et al. Control of Echinochloa sp. in the irrigated rice crop. International Journal of Agronomy, v.2014, p.1-6, 2014. Available from: <http://www.hindawi. com/journals/ija/2014/931840/>. Accessed: Jun. 01, 2016. doi: $10.1155 / 2014 / 931840$.

PINTO J. J. et al. Control of Echinochloa spp. as a function of management methods in flooded rice. Planta Daninha, v.26, p.767-777, 2008. Available from: <http://www.scielo.br/scielo. php? script $=$ sci_arttext $\&$ pid $=\mathrm{S} 0100-83582008000400008>$. Accessed: Jun. 01, 2016. doi: 10.1590/S0100-83582008000400008.

RUIZ-SANTAELLA, J. P. et al. Basis of selectivity of cyhalofopbutyl in Oryza sativa L. Planta, v.223, p.191-199, 2006a. Available from: <http://www.ncbi.nlm.nih.gov/pubmed/16160841>. Accessed: Jun. 01, 2016. doi: 10.1007/s00425-005-0075-1.

RUIZ-SANTAELLA, J. P. et al. Resistance mechanisms to cyhalofop-butyl in a biotype of Echinochloa phyllopogon (Stapf) Koss. from California. Journal of Plant Diseases and Protection, v.10, p.95-100, 2006b. Available from: <http://www. zuechtungskunde.de/ artikel.dll/11-Ruiz-Santaella MTAyMzky. PDF>. Accessed: Jun. 01, 2016. doi: 10.1016/j.cropro.2005.07.016.

VIDOTTO, F. et al. Herbicide sensitivity of Echinochloa spp. accessions in Italian rice fields. Crop Protection, v.26, p.285-293, 2007. Available from: <http://www.sciencedirect.com/science/ article/pii/S026121940600247X>. Accessed: Jun. 01, 2016. doi: 10.1016/j.cropro.2005.07.016 